\title{
Prospective Clinical Comparative Assessment of Intubating Conditions and Neuromuscular Blocking Effects of Two Different Doses of Cisatracurium.
}

\author{
Kailash Prabhudev ${ }^{1}$, Channagouda Hadimani ${ }^{2}$ \\ ${ }^{1}$ Assistant Professor, Department of Anesthesia and Critical Care, MVJ Medical College and Research Hospital, Hoskote, Karnataka, India, ${ }^{2} J u n i o r$ \\ resident, Department of Anesthesia and Critical Care, MVJ Medical College and Research Hospital, Hoskote, Karnataka, India.
}

\section{Abstract}

Background: To study the effects of two different doses of cisatracurium $0.15 \mathrm{mg} / \mathrm{kg}$ and $0.2 \mathrm{mg} / \mathrm{kg}$ regarding intubating conditions, duration of action, hemodynamic stability and allergic reactions. Subjects and Methods: 60 patients posted for elective surgical procedures under general anaesthesia in various surgical disciplines were enrolled into the study and alternatively allocated patients into one of the two study groups of 30 each to receive either $0.15 \mathrm{mg} / \mathrm{kg}$ or $0.2 \mathrm{mg} / \mathrm{kg}$ of cisatracurium. Intubating conditions assessed as excellent, good, poor or not possible and duration of action assessed and noted. PR and BP monitored at regular timed intervals following muscle relaxant and allergic reactions evaluated clinically. Results: $4 \times \mathrm{ED} 95$ dose of cisatracurium had statistically significantly longer duration of action and had produced proportionately excellent intubating conditions as compared to its $3 \times E D 95$ dose. The mean duration of action after $4 \times E D 95$ loading dose was $53.03 \pm 5.75$ minutes and $45.16 \pm 4.41$ minutes after $3 \times E D 95$ dose and the difference was statistically and clinically significant. Proportionately 4×ED 95 dose of Cisatracurium had produced excellent intubating conditions as compared to its $3 \times$ ED 95 dose (90\% vs $70 \%$ ). Differences in hemodynamic changes (pulse rate and blood pressure) after the above doses were clinically insignificant. And none of the patients after either dose showed allergic reactions. Conclusion: Cisatracurium at a higher dose $0.2 \mathrm{mg} / \mathrm{kg}(4 \times \mathrm{ED} 95)$ as compared to its lower dose $0.15 \mathrm{mg} / \mathrm{kg}$ ( $3 \times \mathrm{ED} 95)$ provides longer duration of action and proportionately excellent intubating conditions. Both doses produced stable hemodynamic status without clinically significant changes in PR and BP. No allergic reactions were noted at both the doses.

Keywords: Cisatracurium, intubating conditions, duration of action, PR, ED95 allergic reactions.

Corresponding Author: Dr. Channagouda Hadimani, Junior resident, Department of Anesthesia and Critical Care, MVJ Medical College and Research Hospital, Hoskote, Karnataka, India.

Email: kailashpdev@gmail.com

Received: February 2020

Accepted: February 2020

\section{Introduction}

Neuromuscular block is an essential part of balanced anesthesia. This is achieved by the use of neuromuscular blocking agents which are either depolarizing or nondepolarizing type.

Endotracheal intubation is mandatory for administration of general anesthesia with controlled ventilation. Suxamethonium, a depolarizing muscle relaxant is the gold standard for facilitation of intubation. But the popularity of succinyl choline is questioned by side effects which range from muscle pains after recovery to dangerous arrhythmias and hyperkalemia, and it is contraindicated in many instances.

Cisatracurium, an isomer of atracurium is a potent muscle relaxant. It is a nondepolarizing muscle relaxant (ED95 estimated to be $0.05 \mathrm{mg} / \mathrm{kg}$ ) which does not provoke histamine release. It is known that cisatracurium produces good intubating conditions following a dose of $0.1 \mathrm{mg} / \mathrm{kg}$ to
$0.15 \mathrm{mg} / \mathrm{kg}$ in two minutes. ${ }^{[1]}$ Studies have been done for its use for tracheal intubation and are found that $0.1 \mathrm{mg} / \mathrm{kg}$ (ED95X2) dose of cisatracurium do not create satisfactory intubating conditions. ${ }^{[2]}$

Doses of $3 \times$ ED95 or $4 \times$ ED95 of cisatracurium produce satisfactory intubating conditions when propofol is used as the induction agent. Since propofol itself can provide satisfactory intubating conditions it may affect the quality of the intubating conditions produced by a muscle relaxant. ${ }^{[3]}$ Hence the present study was done to try higher bolus doses $0.15 \mathrm{mg} / \mathrm{kg}$ and $0.2 \mathrm{mg} / \mathrm{kg}$ of cisatracurium, after induction of anesthesia with thiopentone for facilitation of intubation. If found satisfactory, it will be a useful relaxant for endotracheal intubation in patients where succinylcholine is contraindicated.

\section{Subjects and Methods}

A clinical comparative study for the assessment of intubating conditions and neuromuscular blocking effects of two 
different doses, $0.15 \mathrm{mg} / \mathrm{kg}$ and $0.2 \mathrm{mg} / \mathrm{kg}$ of Cisatracurium was undertaken on sixty patients (30 in each group) posted for elective surgical procedures under general anesthesia in various surgical disciplines at $\mathrm{M} \mathrm{V} \mathrm{J}$ medical college \& Research Hospital, Hoskote, Bangalore, during the period November 2016 to September 2018.

\section{Inclusion criteria:}

- Patients belonging to ASA physical status I and II.

- Patients with age group of 18-55 years, of either sex.

- Mallampati class I and II.

Exclusion criteria:

- Patients with airway problems suggesting difficult intubation.

- Allergy to drug, any other history of allergy.

- Patients below the age of 18 years.

- Pregnant and lactating patients...

- Patients receiving drugs known to interact with neuromuscular blocking agents

- Neuromuscular disorders like myasthenia gravis, GB syndrome etc.

After getting ethical clearance from the ethics committee, patients were grouped into two groups alternatively.

Group A: Cisatracurium $0.15 \mathrm{mg} / \mathrm{kg}$ group $(\mathrm{n}=30)$

Group B: Cisatracurium $0.2 \mathrm{mg} / \mathrm{kg}$ group $(\mathrm{n}=30)$

A detailed pre-anaesthetic evaluation including history of previous medical illness, previous surgeries, general examination and appropriate baseline investigations were carried out on the day prior to surgery and recorded. An informed and written consent was taken after explaining the anaesthetic procedure and all patients were given tablet alprazolam $0.25 \mathrm{mg}$ on the previous night and on the morning of surgery. After entry into the operation theatre an intravenous line was secured with $18 \mathrm{G}$ canula. Patients were connected to standard monitors with 3-lead electrocardiograph (ECG), pulse oximetry and NIBP. Inj Fentanyl $1 \mathrm{mcg} / \mathrm{kg}$ and Inj. Glycopyrrolate $0.005 \mathrm{mg} / \mathrm{kg}$ were given. Baseline blood pressure, pulse rate and oxygen saturation were recorded on the operating table. Patients were preoxygenated with $100 \%$ oxygen for 3 minutes. Induced with thiopentone $5 \mathrm{mg} / \mathrm{kg}$. After loss of the eyelash reflex and check ventilation, patients in group A received $0.15 \mathrm{mg} / \mathrm{kg}$ cisatracurium and patients in group B $0.2 \mathrm{mg} / \mathrm{kg}$ cisatracurium. The patients were ventilated for 120 seconds. laryngoscopy was done \& intubated with an appropriate size endotracheal tube. If intubation failed at the first attempt, patients were mask ventilated and further attempts were made after 30 seconds.

The intubating conditions were assessed and classified according to Goldberg et al as,

"Excellent" (easy passage of the endotracheal tube without coughing; vocal cords relaxed),

"Good" (passage of the tube with slight cough; vocal cords relaxed),

"Poor" (passage of the tube with moderate coughing or bucking; some vocal cords movement),

"Not possible" (vocal cords adducted or not visualized; jaw not relaxed).

Pulse rate, blood pressure, $\mathrm{SpO} 2$ were recorded every 5 minutes for 30 minutes and then every 15 minutes until reversal. The anaesthesia was maintained with $02: \mathrm{N} 2 \mathrm{O}$ mixture with isoflurane in the concentration of $0.5-1 \%$. Patients were monitored for any allergic reactions.

When the patient attempts to breath, sensing the bag and clefts in capnogram, time noted and the time from the administration of the bolus dose to this point was taken as duration of action. Either supplemental dose was given or reversed with Inj neostigmine $0.05 \mathrm{mg} / \mathrm{kg}$ and $\mathrm{Inj}$ glycopyrrolate $0.01 \mathrm{mg} / \mathrm{kg}$.

The above observations were recorded and subjected to statistical analysis.

\section{Statistical Methods:}

Descriptive and inferential statistical analysis has been carried out in the present study. Results on continuous measurements are presented on Mean $\square$ SD (Min-Max) and results on categorical measurements are presented in Number (\%). Significance is assessed at $5 \%$ level of significance.

\section{Statistical software:}

The Statistical software namely SAS 9.2, SPSS 15.0, Stata 10.1, MedCalc 9.0.1, N Master Software and Systat 12.0 were used for the analysis of the data and Microsoft word and Excel have been used to generate graphs, tables etc.

\section{Results}

This clinical comparative study for the assessment of intubating conditions and neuromuscular blocking effects of two different doses, $0.15 \mathrm{mg} / \mathrm{kg}$ and $0.2 \mathrm{mg} / \mathrm{kg}$ of cisatracurium was undertaken on sixty patients (30 in each group) posted for elective surgical procedures under general anesthesia in various surgical disciplines at $\mathrm{M} \mathrm{V} \mathrm{J}$ medical college \& Research Hospital, Hoskote, Bangalore, during the period November 2016 to September 2018 and these cases were taken up for the study as outlined in the methodology. Demographic variables like Age, gender, ASA status were not statistically significant.

\section{Age distribution of patients studied}

\begin{tabular}{|l|l|l|l|l|}
\hline \multirow{2}{*}{ Age in years } & \multicolumn{3}{|l|}{ Group A } & Group B \\
\cline { 2 - 5 } & No. & \% & No. & \% \\
\hline $18-30$ & 11 & 36.66 & 14 & 46.66 \\
\hline $31-45$ & 10 & 33.33 & 12 & 40.00 \\
\hline $46-55$ & 9 & 30 & 4 & 13.33 \\
\hline Total & 30 & 100 & 30 & 100 \\
\hline Mean \pm SD & $36.76+12.02$ & $34.46+10.20$ \\
\hline
\end{tabular}

P-value $=0.48$

\section{Gender distribution of patients studied}

\begin{tabular}{|l|l|l|l|l|}
\hline \multirow{2}{*}{ Age in years } & Group A & Group B \\
\cline { 2 - 5 } & No. & $\%$ & No. & \% \\
\hline Male & 14 & 46.66 & 9 & 30.00 \\
\hline Female & 16 & 53.33 & 21 & 70.00 \\
\hline Total & 30 & 100 & 30 & 100 \\
\hline Total & 30 & 100 & 30 & 100 \\
\hline
\end{tabular}

\begin{tabular}{|l|l|l|l|l|}
\hline \multirow{2}{*}{ ASA Grade } & Group A & Group B \\
\cline { 2 - 5 } & No. & \% & No. & \% \\
\hline Grade I & 16 & 53.33 & 12 & 40.00 \\
\hline Grade II & 14 & 46.66 & 18 & 60.00 \\
\hline Total & 30 & 100 & 30 & 100 \\
\hline P-value $=0.58$ & \multicolumn{4}{|l}{} \\
\hline
\end{tabular}


Intubating Conditions: 21 (70\%) patients in group A and 27 $(90 \%)$ in group B were having "Excellent" intubating conditions. 2 (6.66\%) in group A and $2(6.66 \%)$ in group B were having "Good" intubating conditions. 4 (13.33\%) in group A but none in group B were having "Not possible" intubating conditions. Proportionately more number of patients in group B were having "Excellent" intubating conditions but the difference was statistically not significant.

\section{Intubating Conditions of two groups}

\begin{tabular}{|l|l|l|l|l|}
\hline \multirow{2}{*}{$\begin{array}{l}\text { Intubating } \\
\text { Conditions }\end{array}$} & \multicolumn{2}{|l|}{ Group A } & Group B \\
\cline { 2 - 5 } & No. & \% & No. & \% \\
\hline Excellent & 21 & 70.00 & 27 & 90.00 \\
\hline Good & 2 & 6.66 & 2 & 6.66 \\
\hline Poor & 3 & 10.00 & 1 & 3.33 \\
\hline Not possible & 4 & 13.33 & 0 & 0 \\
\hline Total & 30 & 100 & 30 & 100 \\
\hline
\end{tabular}

P-value $=0.22$

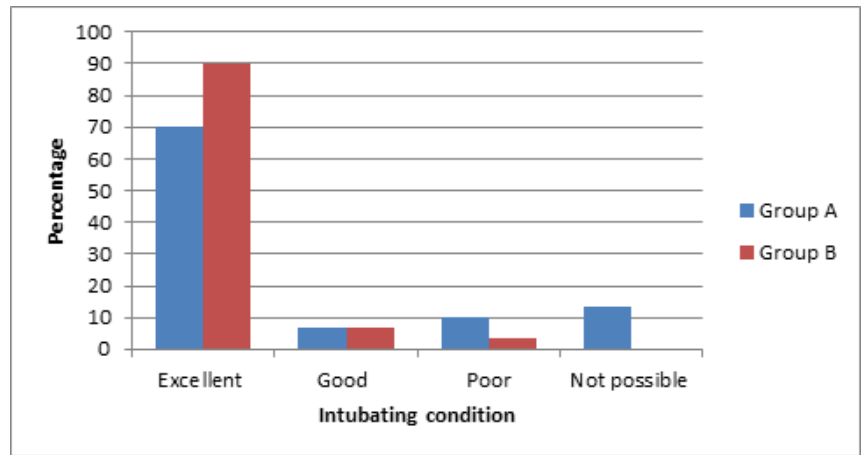

\section{Bar diagram of Intubating conditions}

Duration of action: From the table and diagram, The mean duration of action in group $\mathrm{A}$ was $45.16 \pm 4.41$ minutes and in group B was $53.03 \pm 5.75$ minutes. And this difference is statistically significant.

\section{Comparison of duration of action between two groups}

\begin{tabular}{|l|l|l|l|}
\hline $\begin{array}{l}\text { Mean duration of } \\
\text { action in minutes }\end{array}$ & No of samples & Mean \pm SD & P value \\
\cline { 1 - 3 } Group A & 30 & $45.16 \pm 4.41$ & $\begin{array}{l}\text { The p-value } \\
\text { is }<0.001\end{array}$ \\
\hline Group B & 30 & $53.03 \pm 5.75$ & \\
\hline
\end{tabular}

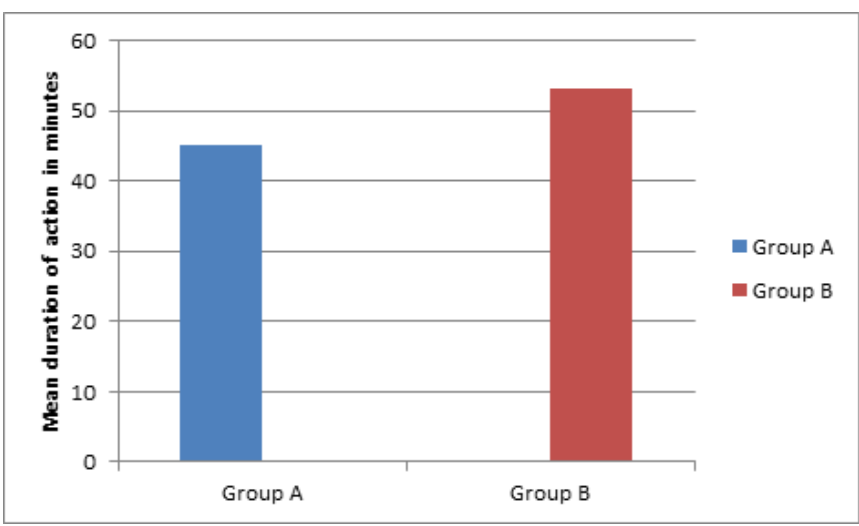

Bar diagram of mean duration of action in both groups From the table and diagram, The mean pulse rate at baseline in group A was $86.7 \pm 9.40 \mathrm{bpm}$ and in group B was $87.33 \pm$ $7.92 \mathrm{bpm}$ and this difference was statistically not significant. The mean pulse rate prior intubation in group A was $95.36 \pm$ $13.86 \mathrm{bpm}$ and in group B was $97.10 \pm 18.57 \mathrm{bpm}$ and this difference was statistically not significant. In the post intubation period, the differences between mean pulse rates of group A and group B were statistically not significant.

\section{Comparison of pulse rate between two groups}

\begin{tabular}{|c|c|c|c|}
\hline Mean Pulse Rate (bpm) & Group A Mean \pm SD & Group B Mean \pm SD & P Value \\
\hline Baseline & $86.7 \pm 9.40$ & $87.33 \pm 7.92$ & The $p$-value is 0.39 \\
\hline Prior intubation & $95.36 \pm 13.86$ & $97.10 \pm 18.57$ & The p-value is 0.34 \\
\hline \multicolumn{4}{|l|}{ Post intubation } \\
\hline $1 \mathrm{~min}$ & $102.3 \pm 14.617$ & $105.56 \pm 20.92$ & The p-value is 0.24 \\
\hline $5 \min$ & $99.633 \pm 14.252$ & $99.4 \pm 17.68$ & The $\mathrm{p}$-value is 0.48 \\
\hline $10 \mathrm{~min}$ & $96 \pm 17.015$ & $94.93 \pm 15.61$ & The $p$-value is 0.40 \\
\hline $15 \mathrm{~min}$ & $97.633 \pm 16.75$ & $90.76 \pm 15.42$ & The $p$-value is 0.051 \\
\hline $20 \mathrm{~min}$ & $94.3 \pm 16.760$ & $93.26 \pm 15.34$ & The $p$-value is 0.40 \\
\hline $25 \mathrm{~min}$ & $95.2 \pm 12.435$ & $92.53 \pm 15.38$ & The $p$-value is 0.23 \\
\hline $30 \mathrm{~min}$ & $91.966 \pm 12.248$ & $90.93 \pm 11.35$ & The $\mathrm{p}$-value is 0.37 \\
\hline $45 \mathrm{~min}$ & $89.866 \pm 12.955$ & $86.33 \pm 17.32$ & The $\mathrm{p}$-value is 0.19 \\
\hline $60 \mathrm{~min}$ & $85.933 \pm 12.434$ & $86.2 \pm 13.47$ & The p-value is 0.47 \\
\hline $75 \mathrm{~min}$ & $85.933 \pm 12.434$ & $84.76 \pm 14.10$ & The $p$-value is 0.73 \\
\hline
\end{tabular}

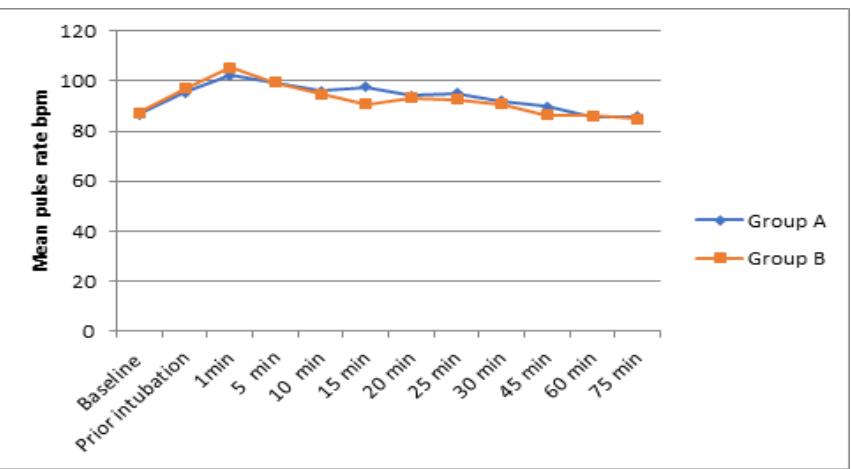

\section{Line diagram of pulse rate in both the groups}

From the table and diagram, The mean systolic blood pressures at baseline in group A and group B were $128.13 \pm$ $12.84 \mathrm{~mm} \mathrm{Hg}$ and $128.26 \pm 9.79 \mathrm{~mm} \mathrm{Hg}$, respectively and this difference was statistically not significant. In post intubation period, the differences between mean systolic blood pressures of group A and group B were not significant.

Comparison of systolic blood pressure between two groups 
Pralkuder \& Fadimani: Intulbating Canditions and Neuramuscular Blacking Effects of Cisatracurium

\begin{tabular}{|c|c|c|c|}
\hline $\begin{array}{l}\text { Mean systolic blood pressure } \\
\text { mm of } \mathrm{Hg}\end{array}$ & $\begin{array}{l}\text { Group A } \\
\text { Mean } \pm \text { SD }\end{array}$ & $\begin{array}{l}\text { Group B } \\
\text { Mean } \pm \text { SD }\end{array}$ & P Value \\
\hline Baseline & $128.13 \pm 12.84$ & $128.26 \pm 9.79$ & The $\mathrm{p}$-value is 0.48 \\
\hline Prior Intubation & $126.6 \pm 14.97$ & $123.6 \pm 13.43$ & The $p$-value is 0.21 \\
\hline \multicolumn{4}{|l|}{ Post intubation } \\
\hline $1 \mathrm{~min}$ & $139.16 \pm 14.38$ & $136.6 \pm 19.77$ & The $\mathrm{p}$-value is 0.28 \\
\hline $5 \mathrm{~min}$ & $116.90 \pm 17.39$ & $116.96 \pm 15.33$ & The p-value is 0.49 \\
\hline $10 \mathrm{~min}$ & $113.50 \pm 18.00$ & $109.26 \pm 13.40$ & The p-value is 0.15 \\
\hline $15 \mathrm{~min}$ & $120.50 \pm 18.48$ & $120.53 \pm 9.59$ & The $\mathrm{p}$-value is 0.49 \\
\hline $20 \mathrm{~min}$ & $128.30 \pm 24.55$ & $128.06 \pm 9.37$ & The $p$-value is 0.48 \\
\hline $25 \mathrm{~min}$ & $120.66 \pm 18.67$ & $122.63 \pm 15.14$ & The $p$-value is 0.33 \\
\hline $30 \mathrm{~min}$ & $119.10 \pm 20.13$ & $119.00 \pm 13.70$ & The $\mathrm{p}$-value is 0.49 \\
\hline $45 \mathrm{~min}$ & $118.16 \pm 18.62$ & $119.90 \pm 12.73$ & The $\mathrm{p}$-value is 0.34 \\
\hline $60 \mathrm{~min}$ & $117.60 \pm 15.94$ & $118.73 \pm 11.26$ & The $p$-value is 0.38 \\
\hline $75 \mathrm{~min}$ & $117.60 \pm 15.94$ & $117.6 \pm 10.63$ & The $p$-value is 0.5 \\
\hline
\end{tabular}

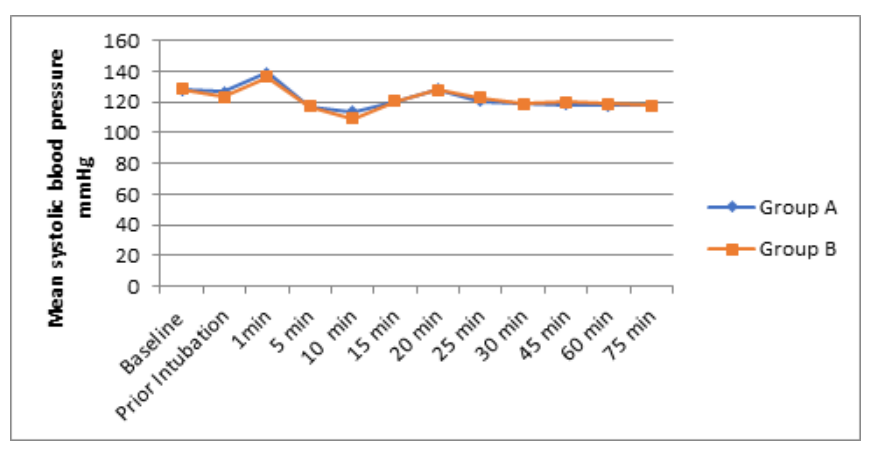

From the table and diagram,

The mean diastolic blood pressures at baseline in group A and group B were $84.33 \pm 8.71 \mathrm{mmHg}$ and $83.66 \pm 5.65$ $\mathrm{mmHg}$, respectively and this difference was statistically not significant. In post intubation period,the differences between mean diastolic blood pressures of group A and group B were not significant.

Comparision of diastolic blood pressure between two groups

Line diagram of systolic blood pressure in both the groups

\begin{tabular}{|l|l|l|l|}
\hline Mean diastolic blood pressure mm of Hg & Group A Mean $\mathbf{E S D}$ & $\begin{array}{l}\text { Group B Mean } \pm \\
\text { SD }\end{array}$ & P Value \\
\hline Baseline & $84.33 \pm 8.71$ & $83.66 \pm 5.65$ & The p-value is 0.36 \\
\hline Prior Intubation & $81.66 \pm 9.08$ & $81.16 \pm 6.10$ & The p-value is 0.40 \\
\hline Post intubation & $89.10 \pm 7.63$ & $84.86 \pm 15.30$ & The p-value is 0.09 \\
\hline $1 \mathrm{~min}$ & $75.43 \pm 12.76$ & $70.16 \pm 12.70$ & The p-value is 0.06 \\
\hline $5 \mathrm{~min}$ & $73.50 \pm 16.05$ & $73.83 \pm 9.62$ & The p-value is 0.46 \\
\hline $10 \mathrm{~min}$ & $76.96 \pm 14.22$ & $76.6 \pm 7.66$ & The p-value is 0.45 \\
\hline $15 \mathrm{~min}$ & $82.76 \pm 20.34$ & $82.13 \pm 6.76$ & The p-value is 0.44 \\
\hline $20 \mathrm{~min}$ & $75.76 \pm 13.05$ & $72.9 \pm 9.87$ & The p-value is 0.17 \\
\hline $25 \mathrm{~min}$ & $75.6 \pm 15.00$ & $74.26 \pm 9.60$ & The p-value is 0.34 \\
\hline $30 \mathrm{~min}$ & $72.40 \pm 11.48$ & $72.36 \pm 9.27$ & The p-value is 0.44 \\
\hline $45 \mathrm{~min}$ & $76.76 \pm 14.28$ & $73.76 \pm 9.87$ & The p-value is 0.17 \\
\hline $60 \mathrm{~min}$ & $76.76 \pm 14.28$ & $73.76 \pm 9.87$ & The p-value is 0.17 \\
\hline $75 \mathrm{~min}$ &
\end{tabular}

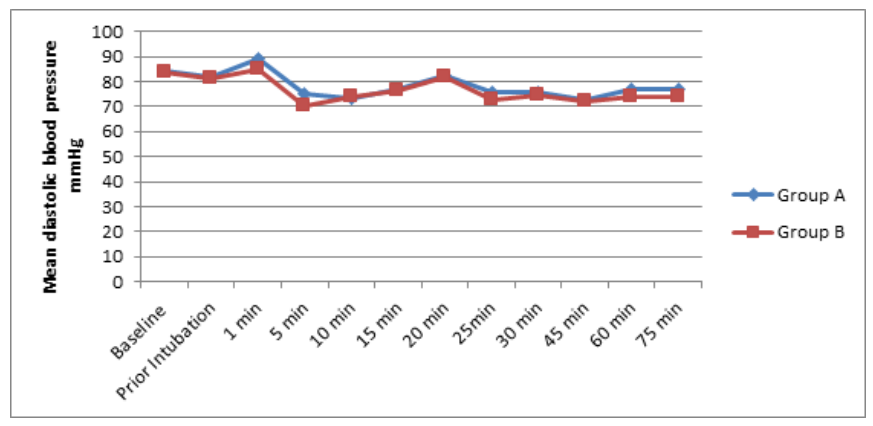

\begin{tabular}{|l|l|l|l|}
\hline SpO2 \% & $\begin{array}{l}\text { Group A } \\
\text { Mean } \pm \text { SD }\end{array}$ & $\begin{array}{l}\text { Group B } \\
\text { Mean } \pm \text { SD }\end{array}$ & P Value \\
\hline Baseline & $98.70 \pm 0.59$ & $98.70 \pm 0.46$ & The p-value is 0.5 \\
\hline $\begin{array}{l}\text { Prior } \\
\text { Intubation }\end{array}$ & $99.63 \pm 0.49$ & $99.63 \pm 0.55$ & The p-value is 0.5 \\
\hline Post intubation & $99.86 \pm 0.50$ & $99.76 \pm 0.43$ & The p-value is 0.21 \\
\hline 1 min & $99.43 \pm 0.50$ & $99.43 \pm 0.72$ & The p-value is 0.5 \\
\hline 5 min & $99.53 \pm 0.50$ & $99.70 \pm 0.46$ & The p-value is 0.10 \\
\hline $10 \mathrm{~min}$ & $99.43 \pm 0.50$ & $99.50 \pm 0.50$ & The p-value is 0.31 \\
\hline $15 \mathrm{~min}$ &
\end{tabular}

Line diagram of diastolic blood pressure in both the groups

From the table and diagram, The mean $\mathrm{SpO} 2$ at baseline in group A and group B were $98.70 \pm 0.59 \%$ and $98.70 \pm$ $0.46 \%$, respectively and this difference was statistically not significant. In post intubation period, the differences between mean $\mathrm{SpO} 2$ of group A and group B were statistically not significant.

Comparison of spo2 between two groups

\begin{tabular}{|l|l|l|l|}
\hline $20 \mathrm{~min}$ & $99.13 \pm 0.34$ & $99.06 \pm 0.25$ & The p-value is 0.20 \\
\hline $25 \mathrm{~min}$ & $99.80 \pm 0.40$ & $99.80 \pm 0.40$ & The p-value is 0.5 \\
\hline $30 \mathrm{~min}$ & $99.76 \pm 0.43$ & $99.76 \pm 0.43$ & The p-value is 0.5 \\
\hline $45 \mathrm{~min}$ & $99.76 \pm 0.43$ & $99.76 \pm 0.43$ & The p-value is 0.5 \\
\hline $60 \mathrm{~min}$ & $99.93 \pm 0.25$ & $99.93 \pm 0.25$ & The p-value is 0.5 \\
\hline $75 \mathrm{~min}$ & $99.93 \pm 0.25$ & $100.00 \pm 0.00$ & The p-value is 0.08 \\
\hline
\end{tabular}




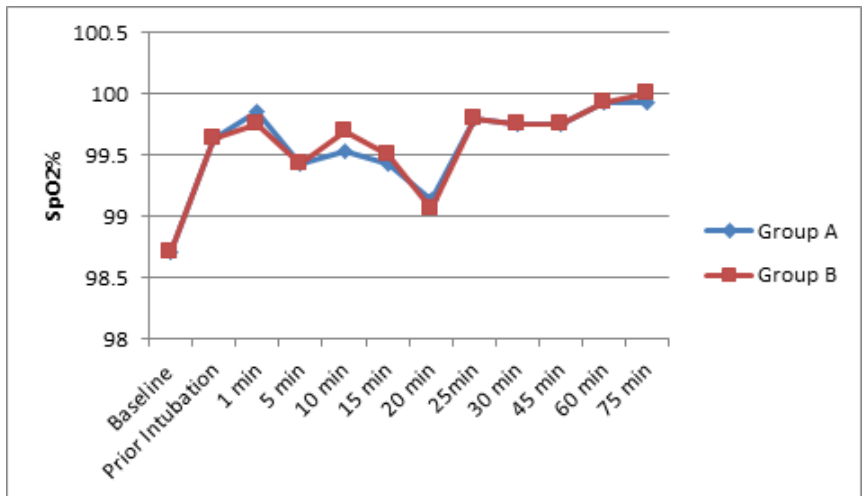

Line diagram of $\mathrm{SpO} 2$ of both the groups

\section{Allergic Reactions}

- None of the patients in our study have showed any allergic reactions

\section{Discussion}

Endotracheal intubation is an important step for administration of general anesthesia with controlled ventilation. The popularity of succinyl choline for facilitation of intubation, is questioned by side effects which range from muscle pains after recovery to dangerous arrhythmias and hyperkalemia, and it is contraindicated in many instances.

Cisatracurium, an isomer of atracurium is a potent muscle relaxant. It is a nondepolarizing muscle relaxant (ED95 estimated to be $0.05 \mathrm{mg} / \mathrm{kg}$ ) which does not provoke histamine release. It is known to produce good intubating conditions following a dose of $0.1 \mathrm{mg} / \mathrm{kg}$ to $0.15 \mathrm{mg} / \mathrm{kg}$ in two minutes. ${ }^{[1]}$

In the present study, we have attempted to compare between two higher doses, $3 \times \mathrm{ED} 95(0.15 \mathrm{mg} / \mathrm{kg})$ and $4 \times \mathrm{ED} 95$ $(0.2 \mathrm{mg} / \mathrm{kg})$ of Cisatracurium for intubating conditions in two minutes. These doses were selected on the basis of previous studies which have found that $2 \times E D 95(0.1 \mathrm{mg} / \mathrm{kg})$ dose of cisatracurium do not create satisfactory intubating conditions. ${ }^{[2]}$

The selection of non-depolarizing muscle relaxant to be used for surgical anaesthesia depends mainly on onset time, intubating conditions, duration of action, cardiovascular effects, pharmacokinetic profile and reversal of neuromuscular blockade.

To avoid discrepancy between two groups, similar anaesthetic techniques were employed in both the groups. 60 patients were divided alternatively into two groups of 30 each (Group A and Group B). All patients in both the groups induced with thiopentone and then,

Group A: $\quad$ Received $0.15 \mathrm{mg} / \mathrm{kg}$ cisatracurium bolus.

Group B: $\quad$ Received $0.2 \mathrm{mg} / \mathrm{kg}$ cisatracurium bolus.

In the present study intubation was attempted at 120 seconds after injection of loading dose. In our study, Excellent intubating conditions were observed in $70 \%$ of patients in group A and $90 \%$ of patients in Group B. Good intubating conditions were observed in $6.66 \%$ of patients in group A and $6.66 \%$ of patients in Group B. Poor intubating conditions were observed in $10 \%$ of patients in group A and $3.33 \%$ of patients in Group B. Not possible intubating conditions were observed in $13.33 \%$ of patients in group A and none of the patients in Group B. Our findings are in consonance with J. M. Rimaniol et al (1997) who observed that good to excellent conditions were present at 2 minutes in $97 \%$ of patients after $0.2 \mathrm{mg} / \mathrm{kg}$ of cisatracurium but in only $80 \%$ after $0.15 \mathrm{mg} / \mathrm{kg}$. 3 A. M. El-Kasaby, H. M. Atef, et al (2010) have observed that after cisatracurium $(0.2 \mathrm{mg} / \mathrm{kg}), 62.5 \%$ and $31.25 \%$ of patients had excellent and good intubating conditions respectively as compared to $37.5 \%$ and $50 \%$ after atracurium $(0.5 \mathrm{mg} / \mathrm{kg}), 2$ minutes after administering the drug, which correlate with our study results. 2 Bluestein LS, Stinson LW, et al (1996) compared the intubating conditions of cisatracurium $0.1 \mathrm{mg} / \mathrm{kg}$ ( $2 \times \mathrm{ED} 95), 0.15 \mathrm{mg} / \mathrm{kg}(3 \times \mathrm{ED} 95)$ and $0.2 \mathrm{mg} / \mathrm{kg}(4 \times \mathrm{ED} 95)$ and atracurium $0.5 \mathrm{mg} / \mathrm{kg}$

$(2 \times E D$ 95) during propofol/fentanyl

anaesthesia. Good or excellent intubation conditions were produced in $89 \%$ of patients two min following an initial dose of $0.1 \mathrm{mg} / \mathrm{kg}$ cisatracurium and in $100 \%$ of patients $1.5 \mathrm{~min}$ following an initial dose of 0.15 or 0.2 $\mathrm{mg} / \mathrm{kg}$ cisatracurium, which correlate with our study results. 4 Schmautz E, Deriaz H, et al (1994) concluded that doses of $0.15 \mathrm{mg} / \mathrm{kg}(3 \times \mathrm{ED} 95)$ and $0.2 \mathrm{mg} / \mathrm{kg}(4 \times \mathrm{ED} 95)$ of cisatracurium, as components of a propofol/nitrous oxide/oxygen induction intubation technique, may produce generally good or excellent conditions of intubation in 2.0 and $1.5 \mathrm{~min}$, respectively. ${ }^{[5]}$ These findings correlate with our study. Hyunjung Lee, Sinho Jeong, Cheolhun Choi, Hyejin Jeong, Seongheon Lee, and Seongwook Jeong. Anesthesiologist's satisfaction using between cisatracurium and rocuronium for the intubation in the anesthesia induced by remifentanil and propofol. Korean J Anesthesiol 2013 Jan;64(1):34-39. ${ }^{[6]}$ These findings correlate with our study In our present study, duration of action of muscle relaxant was noted as the time from injection of loading dose to the patient's first attempts at spontaneous breathing. The mean duration of action of loading dose in our study was $45.16 \pm 4.41$ minutes in group A and $53.03 \pm 5.75$ minutes in Group B. The observed difference between the two groups was 8 minutes and which was statistically significant $(\mathrm{p}<0.001)$ with $0.2 \mathrm{mg} / \mathrm{kg}$ dose of cisatracurium having a longer duration of action. In a similar study by Prakash Jammar et al in 2017, the difference in duration of action was 9 minutes. It correlates with our study. ${ }^{[7]}$ Amini Shahram et al (2011) studied effects of different doses of cisatracurium on appropriate time for endotracheal intubation and hemodynamic changes during anaesthesia and found that the mean clinical duration of action with $0.15 \mathrm{mg} / \mathrm{kg}$ was $44.93 \pm 5.40$ minutes while with $0.2 \mathrm{mg} / \mathrm{kg}$ was $57.03 \pm 4.21$ minutes, which correlates with our study. ${ }^{[8]}$ Bluestein LS, Stinson LW, et al (1996) reported that increasing the initial dose of cisatracurium (from 0.1 to 0.15 and $0.2 \mathrm{mg} / \mathrm{kg}$ ) increased the mean time of clinically effective duration (45 to 55 and $61 \mathrm{~min}$ ) respectively, which correlates with our study results. ${ }^{[4]}$ Jean-Yves Lepage, Jean-Marc Malinovsky, et al (1996) concluded that time to $25 \%$ recovery of T1\% (duration of action) of atracurium $(0.5 \mathrm{mg} / \mathrm{kg})$ and cisatracurium $(0.1,0.2,0.25 \mathrm{mg} / \mathrm{kg})$ was $42,33,55$ and 79 min respectively which infers that increasing the dose of cisatracurium prolongs its duration of action. ${ }^{[9]}$ These findings correlate with our study. 
In our study, baseline preoperative pulse rate was $86.7 \pm 9.40$ bpm in Group A and 87.33 $\pm 7.92 \mathrm{bpm}$ in Group B. Baseline preoperative mean systolic blood pressure was $128.13 \pm 12.84 \mathrm{mmHg}$ in Group A and $128.26 \pm 9.79 \mathrm{mmHg}$ in Group B and the mean diastolic blood pressure was 84.33 $\pm 8.71 \mathrm{mmHg}$ and $83.66 \pm 5.65 \mathrm{mmHg}$ in Group $\mathrm{A}$ and in Group B, respectively.

Bisbenzylquinolinium compounds, in general tend to cause histamine release, which can result in facial flushing and hemodynamic aberrations. The cardiovascular effects normally noted secondary to histamine release are a decrease in mean arterial pressure and a compensatory increase in heart rate. These responses normally are transient and are related to both the size of the dose of the relaxant administered and the time course over which the relaxant is given. ${ }^{[10]}$

The circulatory changes are transient, occurring 60-90 seconds after administration of atracurium and disappearing within 5 minutes. Cisatracurium is devoid of histaminereleasing effects, so that cardiovascular changes do not accompany the rapid IV administration of even large doses $(8 \times$ ED 95$)$ of cisatracurium. ${ }^{[11]}$ In our present study, pulse rate and mean systolic and diastolic pressures were noted every 5 minutes for 30 minutes and then every 15 minutes until reversal, after administering the muscle relaxant cisatracurium, $0.15 \mathrm{mg} / \mathrm{kg}$ in Group A and $0.2 \mathrm{mg} / \mathrm{kg}$ in Group B. Clinically significant changes were defined as deviations of more than $20 \%$ from the basal preoperative value. ${ }^{[10]}$ In our study, no significant differences in mean pulse rates and mean blood pressures were noted between Group A and B after administration of cisatracurium. El-Kasaby AM, H. M. Atef, et al (2010) stated that hemodynamic stability for both $\mathrm{HR}$ and MAP were more evident among higher doses of cisatracurium (4xED95 and 6xED95), which correlates with our study. ${ }^{[2]}$ Agavelian EG and Arkharova TB (1999) reported that cisatracurium in a dose of $0.15 \mathrm{mg}$ did not produce fluctuation in hemodynamic parameters. ${ }^{[12]}$ Schramm NM, Papousek A, et al (1998) stated that after cisatracurium $(0.15 \mathrm{mg} / \mathrm{kg})$, MAP and HR did not change significantly, which correlates with our study. ${ }^{[13]}$ Jean-Yves Lepage, et al (1996) reported in their study that bolus administration of cisatracurium at doses up to $5 \times \mathrm{ED} 95$ caused no dose-related clinically significant effects on HR or MAP, which correlates with our study. ${ }^{[9]}$ Soukup J, Doenicke A, Hoernecke R, Vorhammer B, Seebauer A, Moss J. [Cardiovascular effects after bolus administration of cisatracurium. A comparison with vecuronium]. Anaesthesist. 1996 Nov;45(11):1024-9. ${ }^{[14]}$

In our study, none of the patients have showed any allergic reactions. Allergic reactions (due to histamine release) like skin rashes, bronchospasm and hemodynamic changes were not noted in any of the patients. Atracurium releases histamine after $3 \times$ ED 95 dose. It contains tertiary ammonium ions which are divalent, thus they cross link cell surface IgE and precipitate mediator release from mast cells and basophils. Cisatracurium is devoid of histamine releasing effects even after a large dose $\left(8 \times\right.$ ED 95). ${ }^{[11]}$ El-Kasaby AM, H. M. Atef, et al (2010) reported that no signs of histamine release were noted after different doses of cisatracurium $(2,4$ or $6 \times \mathrm{ED} 95)$ while it was noted with atracurium $(2 \times \mathrm{ED} 95$ dose). These findings correlate with our study. ${ }^{[2]}$ Bluestein
LS, Stinson LW, et al (1996) reported that flushing occurred in $2 / 20$ patients treated with atracurium $(0.5 \mathrm{mg} / \mathrm{kg})$ and in $0 / 60$ patients treated with cisatracurium $(0.1,0.15$ and $0.15 \mathrm{mg} / \mathrm{kg}$ ), which correlates with our study. ${ }^{[4]}$ Jean-Yves Lepage, Jean-Marc Malinovsky, et al (1996) reported that there were no changes in plasma histamine concentration during the first 5 min after administration of cisatracurium at doses up to $5 \times \mathrm{ED} 95$ injected over 5-10 seconds. No cutaneous flushing or bronchospasm was noted. ${ }^{[9]}$ The above findings are in consonance with our study. Cynthia A. Lien, Matthew R. Belmont, et al (1995) stated that no cutaneous flushing was noted after rapid injection of doses up to and including $8 \times$ ED 95 cisatracurium, which correlates with our study.10 Littlejohn IH, Abhay K, et al (1995) concluded that there was no clinical evidence of histamine release in the groups receiving different doses of cisatracurium, which correlates with our study. ${ }^{[15]}$

\section{Conclusion}

Cisatracurium at a higher dose $0.2 \mathrm{mg} / \mathrm{kg}(4 \times \mathrm{ED} 95)$ as compared to its lower dose $0.15 \mathrm{mg} / \mathrm{kg}(3 \times \mathrm{ED} 95)$ provides longer duration of action and proportionately excellent intubating conditions. Both doses produced stable hemodynamic status without clinically significant changes in PR and BP. No allergic reactions were noted at both the doses.

Hence cisatracurium $0.2 \mathrm{mg} / \mathrm{kg}$ produces favourable intubating conditions in two minutes and may be considered for facilitating intubation keeping in mind its long duration of action compared to succinyl choline.

\section{References}

1. Morgan GE, Mikhail MS, Murray MJ. Anesthesiologist's satisfaction using between cisatracurium and rocuronium for the intubation in the anesthesia induced by remifentanil and propofol. Clinical Anaesthesiology; 3rd Edition: pp 192-193.

2. El-Kasaby AM, Atef HM, Helmy AM, El-Nasr MA. Cisatracurium in different doses versus atracurium during general anaesthesia for abdominal surgery. Saudi J Anaesth 2010; 4(3): 152-157.

3. Rimaniol JM, Kersuzan Y, Duvaldestin P. Intubating conditions using cisatracurium after induction of anaesthesia with thiopentone. Anaesthesia 1997;52: 998-1014.

4. Linda S. Bluestein, Lawrence W. Stinson Jr., Robert L. Lennon DO, Stephen N. Quessy, Rebecca M. Wilson. Evaluation of cisatracurium, a new neuromuscular blocking agent, for tracheal intubation. Can J Anaesth 1996; 43(8): 925-31.

5. Schmautz E, Deriaz H, Vrillon M. Evaluation of $51 \mathrm{~W} 89$ for endotracheal intubation in surgical patients during N2O/O2/propofol anesthesia. Anesthesiology. 1994; 81: 1081.

6. Hyunjung Lee, Sinho Jeong, Cheolhun Choi, Hyejin Jeong, Seongheon Lee, Seongwook Jeong. Anesthesiologist's satisfaction using between cisatracurium and rocuronium for the intubation in the anesthesia induced by remifentanil and propofol. Korean J Anesthesiol 2013 Jan;64(1):3439.

7. Jammar P, Pathak DG, Begum I, Chauhan RC. A clinical comparative study of two intubating doses of cis-atracurium during general anaesthesia for gynaecological surgery. Int J Basic Clin Pharmacol 2017;6:1206-10.

8. Amini S, Akramifard AA, Roudbari M, Comparison of the effects of different doses of cisatracurium on appropriate time for endotracheal intubation and hemodynamic changes during anesthesia. Zahedan J Res Med Sci (ZJRMS) 2011;13(7):13-17.

9. Lepage JY, Malinovsky JM, Malinge M, Lechevalier T, Dupuch C, Cozian A, et al. Pharmacodynamic dose-response and safety study of Cisatracurium (51W89) in adult surgical patients during N2O-O2-opioid 
anaesthesia. Anesth Analg 1996;83:823-829.

10. Lien CA, Belmont MR, Abalos A, Eppich L, Quessy S, Abou-Donia MM, Savarese JJ. The cardiovascular effects and histamine releasing properties of 51W89 in patients receiving nitrous oxide/opioid/barbiturate anaesthesia. Anesthesiology 1995;82:1131-1138.

11. Stoelting RK \& Hillier SC. Neuromuscular-Blockingdrugs, Chapter 8 In: Pharmacology and Physiology in Anesthetic Practice, 4th Ed. Philadelphia:

12. Agavelian EG, Arkharova TB. Evaluation of the effectiveness of a new myorelaxant nimbex (cisatracurium besilate) in children. Anesteziol
Reanimatol. 1999 Jul-Aug;(4):16-8.

13. Schramm WM, Papousek A, Michalek-Sauberer A, Czech T, Illievich U. The Cerebral and Cardiovascular Effects of Cisatracurium and Atracurium in Neurosurgical Patients. Anesth Analg 1998;86:123-127.

14. Soukup J, Doenicke A, Hoernecke R, Vorhammer B, Seebauer A, Moss J. Cardiovascular effects after bolus administration of cisatracurium. A comparison with vecuronium. Anaesthesist. 1996 Nov;45(11):1024-9.

15. Littlejohn IH, Abhay K, EL Sayed A, Broomhead CJ, Duvaldestin P, Flynn PJ. Intubating conditions following $1 \mathrm{R}$ CIS, 1 'R CIS atracurium (51W89). Anaesthesia 1995 June; 50 (6): 499-5.

Copyright: (C) the author(s), 2020. It is an open-access article distributed under the terms of the Creative Commons Attribution License (CC BY 4.0), which permits authors to retain ownership of the copyright for their content, and allow anyone to download, reuse, reprint, modify, distribute and/or copy the content as long as the original authors and source are cited.

How to cite this article: Prabhudev K, Hadimani C. A Prospective Clinical Comparative Assessment of Intubating Conditions and Neuromuscular Blocking Effects of Two Different Doses of Cisatracurium. Acad. Anesthesiol. Int. 2020;5(1):34-40.

DOI: dx.doi.org/10.21276/aan.2020.5.1.7

Source of Support: Nil, Conflict of Interest: None declared. 